\title{
Cytokine Storm in Head Injury Patients and its Management in COVID-19 Era
}

Abdur Rahman', A. H. M. Ataullah², Umme Farzana Akter ${ }^{3}$, Rubaya Rashid ${ }^{4}$, Sabrina Rahman ${ }^{5}$, Md. Shalah Uddin ${ }^{6}$, Masum Rahman ${ }^{7}$, Ivan David Lozada-Martinez ${ }^{8}$, Md Moshiur Rahman**

${ }^{1}$ Coordinator of Demyelinating Diseases Program. Department of Neurology, National Medical Center XXI Century, Specialty Hospital. Instituto Mexicano del Seguro Social (IMSS).

${ }^{2}$ Coordinator of Brain Tumor and Epilepsy Surgery Program. Department of Neurosurgery. National Medical Center XXI Century, Specialty Hospital. Instituto Mexicano del Seguro Social (IMSS).

${ }^{3}$ Second year resident. Department of Neurology, National Medical Center XXI Century, Specialty Hospital. Instituto Mexicano del Seguro Social (IMSS).

${ }^{4}$ Third year resident. Department of Neurosurgery. National Medical Center XXI Century, Specialty Hospital. Instituto Mexicano del Seguro Social (IMSS).

*Corresponding Author: Md Moshiur Rahman, Neurosurgery Department, Holy Family Red Crescent Medical College, Dhaka, Bangladesh Received date: January 08, 2021; Accepted date: February 26, 2021; Published date: March 05, 2021

Citation: Abdur Rahman, A. H. M. Ataullah, Umme Farzana Akter, Rubaya Rashid,. Md Moshiur Rahman., (2021) Cytokine Storm in Head Injury Patients and its Management in COVID-19 Era. J. Neuroscience and Neurological Surgery. 8(2); DOI:10.31579/2578-8868/153

Copyright: (C) 2021 Md Moshiur Rahman, This is an open-access article distributed under the terms of The Creative Commons Attribution License, which permits unrestricted use, distribution, and reproduction in any medium, provided the original author and source are credited

COVID-19 pandemic puts the world in a terrible situation and makes every disease management challenging especially the trauma-related cases. Head injury is by far the most significant part of trauma-related mortality worldwide. It also affects economically and has a negative social impact. [1]

A head injury sometimes interchangeably used as traumatic brain injury (TBI), can lead to neuro-inflammation. Neuro-inflammation can also be triggered by Systemic inflammation and inflammation can lead to disruption of the blood-brain barrier. Previously it was thought that our blood-brain barrier protects the brain from insult. But now we understand that inflammatory mediators can damage the blood-brain barrier and make it leaky or hyper-permeable to any substance. [2]

Cytokine storm is a special term applied to unregulated cytokine release in response to an infection or some other stimuli like trauma. Particularly cytokines like interleukin (IL)-1 $\beta$, IL-6, and tumor necrosis factor (TNF)$\alpha$ play the key role. The main pathogenesis is complex but it includes loss of control of the pro-inflammatory cytokine productions in all levels. [3,4]

These days it is well established that brain damage after a head injury occurs in two distinct phases. One is due to direct external mechanical force and another is due to a secondary inflammatory phase, where numerous types of cytokines are responsible like interleukin one (IL-1), IL-6, and tumor necrosis factor-alpha (TNF- $\alpha$ ). The level of IL-6 is usually negligible $(1-23 \mathrm{pg} / \mathrm{ml})$ or even undetectable in CSF. But after a head injury, the amount of cytokine rises and it can be massive. A study reported IL-6 level in CSF of a severe TBI patient was 35,500 pg/ml, which is almost 1500 times greater than normal and in another patient with severe TBI, the reported IL-8 level in CSF was as high as 3,36,500 $\mathrm{pg} / \mathrm{ml}$. These cytokines result in further damage by causing vasogenic edema, oxidative stress, polymorphonuclear cell recruitment, and activating resident microglia as well as platelets. [3,5]

We all know and it's an established fact that COVID-19 infection can also induce cytokine storm. So, if a head injury patient also gets COVID-19, it's devastating and deadly. [6]
There are several ways that we can manage cytokine storms in head injury patients. Apart from general measures of head injury we now want to focus on some medications to control storms. We can classify the drugs into two groups based on their mechanism of action. The first one acts with a known mechanism of action and the other acts through an unknown mechanism of action but we know they work. Proof of their action can be confirmed by serial evaluation in the level of inflammatory mediator's level before and after giving the drugs or by observing an alternative inflammatory outcome. [5]

\section{Drugs with known anti-inflammatory action}

- Glucocorticoids: Have a wide range of anti-inflammatory action. They inhibit the arachidonic acid metabolism pathway thus inhibit interleukin synthesis, suppress cell-mediated immunity by decreasing leukocytes number and their activity. [5]

- $\quad$ Non-steroidal anti-inflammatory drugs (NSAIDS) A potent analgesic and it inhibits inflammation by inhibiting cyclooxygenase pathway. [5]

- $\quad$ TNF $\alpha$ inhibitors: TNF $\alpha$ rapidly induced by traumatic injury. Infliximab and adalimumab are some $\mathrm{TNF} \alpha$ inhibitors that inhibit its production. [7]

- Interleukin 1 inhibitors: IL-1 expression increases rapidly after traumatic injury. Anakinra is an IL-1 inhibitor. [5]

- Phosphodiesterase Inhibitors: Limit the breakdown of the 2nd messenger cyclic AMP. cAMP transiently increases following TBI. Rolipram is a specific inhibitor of phosphodiesterase. [8]

\section{Drugs with unknown anti-inflammatory action}

- Minocycline: is a member of the antibiotic tetracycline family that can penetrate the BBB because of its lipid nature. It has an anti-inflammatory action in a concentration higher than needed for antimicrobial action. [9] 
- Progesterone: Progesterone is a hormone that has multiple anti-inflammatory actions. [10]

- Erythropoietin: Erythropoietin stimulate proliferation of erythrocyte precursors in the bone marrow. When tested in a variety of animal models of head injury, erythropoietin has antiapoptotic and anti-oxidative activities. [11]

- Statins: A HMG-CoA reductase inhibitor and has an antiinflammatory effect. [5]

- N-acetylcysteine: An anti-oxidant, can act as an antiinflammatory drug probably by neutralizing oxidative stress. [5]

What extra precaution should be taken in the COVID-19 era

- Patient of head injury without COVID-19 co-infection: We should strictly be careful about these patients that they didn't get this infection at the same time. Because it can be lifethreatening and for this, we have to treat them in a separate zone (including the investigation facility, ICU, operation theater, and others).

- Patient of head injury with COVID-19 co-infection: These people are at a peak of a double threat. Careful examination, assessment, and timed approach should be ensured.

\section{References}

1. Pinggera D, Klein B, Thomé C, Grassner L. The influence of the COVID-19 pandemic on traumatic brain injuries in Tyrol: experiences from a state under lockdown. Eur J Trauma Emerg Surg [Internet]. 2020;(0123456789):3-8.

2. Debby Hamilton, MD M. NEUROINFLAMMATION: THE BRAIN IS ON FIRE IN A CYTOKINE STORM
[Internet]. NZ: 0800439633 | AUS: 1800770 904. 2017 [cited 2021 Apr 1].

3. Sordillo PP, Sordillo LA, Helson L. Bifunctional role of pro-inflammatory cytokines after traumatic brain injury. Brain Inj [Internet]. 2016 Jul 28;30(9):1043-1053.

4. Ye Q, Wang B, Mao J. The pathogenesis and treatment of the 'Cytokine Storm'' in COVID-19.' J Infect [Internet]. 2020;80(6):607-613.

5. Bergold PJ. Treatment of traumatic brain injury with antiinflammatory drugs. Exp Neurol [Internet]. 2016 Jan;275:367-380.

6. Tang Y, Liu J, Zhang D, Xu Z, Ji J, Wen C. Cytokine Storm in COVID-19: The Current Evidence and Treatment Strategies. Front Immunol. 2020;11(July):1-13.

7. Paiva WS, Correia AD, Marie SK. Neuroinflammatory responses to traumatic brain injury. Neuropsychiatr Dis Treat. 2015;11:773-774.

8. Atkins CM, Cepero ML, Kang Y, Liebl DJ, Dietrich WD. Effects of early rolipram treatment on histopathological outcome after controlled cortical impact injury in mice. Neurosci Lett [Internet]. 2013;532(1):1-6.

9. Garrido-Mesa N, Zarzuelo A, Gálvez J. What is behind the non-antibiotic properties of minocycline? Pharmacol Res [Internet]. 2013;67(1):18-30.

10. Tang H, Hua F, Wang J, Yousuf S, Atif F, Sayeed I, et al. Progesterone and Vitamin D combination therapy modulates inflammatory response after traumatic brain injury. Brain Inj [Internet]. 2015;29(10):1165-1174.

11. Radosevich JJ, Patanwala AE, Erstad BL. Emerging pharmacological agents to improve survival from traumatic brain injury. Brain Inj. 2013;27(13-14):14921499.
This work is licensed under Creative Commons Attribution 4.0 License

To Submit Your Article Click Here: Submit Manuscript

DOI: $10.31579 / 2578-8868 / 154$
Ready to submit your research? Choose Auctores and benefit from:

* fast, convenient online submission

* rigorous peer review by experienced research in your field

* rapid publication on acceptance

* authors retain copyrights

* unique DOI for all articles

* immediate, unrestricted online access

At Auctores, research is always in progress.

Learn more www.auctoresonline.org/journals/neuroscience-andneurological-surgery 